NBER WORKING PAPER SERIES

\title{
CORPORATE OWNERSHIP IN FRANCE: THE IMPORTANCE OF HISTORY
}

\author{
Antoin E. Murphy \\ Working Paper 10716 \\ http://www.nber.org/papers/w10716
NATIONAL BUREAU OF ECONOMIC RESEARCH 1050 Massachusetts Avenue
Cambridge, MA 02138
August 2004

My thanks to Michel Lutfalla, Roger Nougaret (Crédit Lyonnais), Cormac Ó Gráda (Department of Economics, University College Dublin), Daniel Raff (Wharton School) and two anonymous referees for their assistance with this paper. The usual disclaimer applies. The views expressed herein are those of the author(s) and not necessarily those of the National Bureau of Economic Research.

(C2004 by Antoin E. Murphy. All rights reserved. Short sections of text, not to exceed two paragraphs, may be quoted without explicit permission provided that full credit, including $\odot$ notice, is given to the source. 
How Much Might Universal Health Insurance Reduce Socioeconomic Disparities in Health? A Comparison of the US and Canada

Antoin E. Murphy

NBER Working Paper No. 10716

August 2004

JEL No. B1, Go, G3, N2

\begin{abstract}
This paper attempts to show the importance of history in influencing the structure of corporate ownership in France. The strong concentration of family ownership in France is traced to historical weaknesses in the money and capital markets that forced families to have recourse to self-financing. The weaknesses in the money and capital markets were greatly influenced by two eighteenth century financial traumas arising from John Law's Mississippi System (1716-20) and the financing of the French Revolution through the issue of the assignats in the 1790s. These financial traumas delayed significantly the emergence of banks and the capital market. Further historical factors influencing French corporate ownership were the changes in the inheritance law system at the start of the nineteenth century and, more recently, the emphasis on a pay-as-you-go pension system.

Antoin E. Murphy

Department of Economics

Trinity College Dublin

Dublin 2

Ireland

aemurphy@tcd.ie
\end{abstract}


The French model of corporate ownership and control is quite distinct from the AngloAmerican model. It has been described as an insider model because it contains a high degree of concentration of ownership, while the wider dispersion of ownership characterised by the U.K. and U.S. models has been termed an outsider model. Why are there such widely differing models between France, and, indeed, many Continental European countries, on the one hand, and the U.S. and the U.K., on the other? La Porta, Lopez-De-Silvanes and Shleifer (1998) have advanced the view that ownership in capital markets is concentrated where there is an absence of strong investor protection embodied in the legal system and regulatory arrangements. La Porta et al. highlight the role of contemporary institutions but downplay, aside from legal developments, the role of historical factors in shaping the structure of capital markets. More recently La Porta, Lopez-de-Silanes, Shleifer and Vishny (2000) asserted that:

Common law countries have the strongest protection of outside investors - both shareholders and creditors - whereas French civil law countries have the weakest protection. $(2000,8)$

Their explanation appears to be that the legal system and regulatory controls determine the structure of corporate ownership. The civil law system is perceived to be linked to a system of weaker control and protection for investors, ergo, it is natural to find a high degree of concentration of ownership in countries such as France because of investors trepidation about investing in a relatively unprotected investment environment. In a post Enron, Tyco, WorldCom world French jurists and financiers might be permitted a wry smile at the implication that the common law system is linked to a strong system of corporate control. ${ }^{1}$

This paper emphasises the importance of history in the shaping of corporate ownership structures. The theme of this paper is that historical elements can produce profound shocks and deep after waves, the effects of which move through an economy for many generations fashioning the collective psyche of people in such a way as to present barriers to innovation and change. The financing of a corporation may arise in three ways: (1) bank borrowing; (2) borrowing from the capital market; (3) self-financing through the use of retained profits. Borrowing from the banking sector and the capital markets dilutes the ownership of a

\footnotetext{
${ }^{1}$ By the end of December 2000 Enron had a market capitalization of over $\$ 60$ billion and had been ranked, by Fortune Magazine as the most innovative large company in the United States. Its bankruptcy raises the issue of corporate governance in the U.S. Healy and Palepu (2003) made the following observations:

'Despite what they call an elaborate corporate governance network, Enron was able to attract large sums of capital to fund a questionable business model, conceal its true performance through a series of accounting and financial manoeuvres and hype its stock to unsustainable levels.'
} 
corporation. Self-financing, on the other hand, strengthens the concentration of ownership. In France over the last three hundred years historical factors have produced a weak capital and banking structure. Because of these weaknesses there has been, until relatively recently, a significant reliance on self-financing. Self-financing in turn implies that ownership remains concentrated in the hands of individuals and families.

Chart 1 outlines some of the most significant historical factors that have influenced the structure of corporate ownership in France. The presentation starts with two major financial traumas in the eighteenth century. These were (1) the rise and collapse of John Law's Mississippi System and (2) the hyperinflationary experience generated by the assignats during the French Revolution. It is contended that these financial traumas, reinforced in the nineteenth century through the collapses of the Crédit Mobilier and the Union Générale, produced a weak banking and capital market structure in France. Deprived of access to banks and capital markets entrepreneurs developed the tradition of reliance on self-financing. This self-financing led to high degrees of concentration of ownership in France. Chart 1 suggests that this self-financing tradition was reinforced by a further historical factor, namely the changes in the inheritance law introduced at the start of the nineteenth century by Napoleon. Primogeniture had been perceived by the revolutionaries as a system that had aided and abetted the survival and strength of the aristocracy. The new post-revolutionary regime, embodied in the Napoleonic code, destroyed the system of primogeniture and replaced it with one based on an equal allocation of property rights amongst all the children in the family. Younger children could no longer be disinherited. The property of the parents was deemed, in large part, to be the property of the children after the death of the former. Paradoxically, this element involves a legal dimension, but not the type of legal dimension that La Porta et al. $(1998,2000)$ envisaged. In the French civil law it is practically impossible to disinherit one's offspring. Faced with the potential 'idiot heir' problem families have successfully used the grandes écoles system to provide educated new leaders of the next generation. Adept recourse to trusts (les indivisions) and insurance has enabled family wealth to be transferred from generation to generation, minimising in the process the burden of inheritance taxes. Add to this legal change favouring the rights of all the children, a type of cultural mentalite that each generation is just the temporary custodian of the family's property (patrimoine) faced with the objective of passing it on in even better shape to the next generation, and one finds a different set of factors that helped shape the development of France's corporate ownership structure. 
Chart 1 also incorporates a section dealing with state involvement in the economy. The state has always been a major player in the French economy since the days of Jean Baptiste Colbert (1619-83), who, during his period as Controller General of Finances, provided a template for sizeable intervention by the state in the economy. Further manifestations in the form of nineteenth century Saint-Simonianism and, later, socialism meant that France experienced bouts of nationalizations and privatizations that greatly influenced the balance between state and private sector ownership of French companies. Finally, the state's approach to pension funding is believed to be an important recent contributory factor to the ownership mix in that the pay-as-you-go system in France has led to relatively small pension fund/insurance involvement in the equity market.

These factors emphasising the historical factors that created the tradition of reliance on selffinancing, the legal and cultural mix inherent in property ownership and the state's invovement in the market are presented as helping to explain, at least in part, the current structure of family corporate ownership in France.

This paper starts with an overview of the current situation relating to corporate ownership in France. From there it moves back to the past to show how the failures of the banking system in 1720 and the assignats experiment in the 1790s, along with the collapse of the stock market in 1720, had deep effects on the emergence of the an efficient banking and capital market structure in France. It will be contended that reliance on the self-financing of corporations was a natural outcome of the difficulties of both the banking system and the capital market. The change in the inheritance laws at the turn of the nineteenth century will be shown to have been a further contributory factor in the embedding of the family in French corporate life. The pension system in France will be presented to explain the sluggish growth of institutional investment in French companies relative to their counterparts in the U.S. and U.K. in the second half of the twentieth century.

Finally, three examples of the growth of family controlled companies, car manufacturers Peugeot, cosmetic producer L'Oréal, and tyre manufacturers Michelin are presented to provide some support for the underlying themes of the paper. These companies also serve to counter Easterbrook's (1997) view that 'a high concentration of ownership is associated with lesser efficiency'. 


\section{The Current Corporate Ownership Structure in France}

The ownership of companies in France has frequently been a very hot political issue. In the 1930s the Prime Minister, Edouard Daladier, vehemently criticised the two hundred 'grandes familles' whom he contended controlled all aspects of French business life as well as the Banque de France, the stock exchange and the press. Daladier's two hundred big families have been shown to be a myth (Anderson, 1965). Nevertheless, a wider range of families does exercise a highly significant part in the ownership of French companies.

Three salient features of France's current corporate ownership structure are (1) concentration of ownership; (2) extensive family ownership; (3) the role of holding companies. Bloch and Kremp (2001) in their recent study of French companies have shown that 'concentration of direct ownership and voting power is very high in France'. They found that 'Around $40 \%$ of unlisted firms have, as first shareholder, individuals owning directly more than $50 \%$ of the capital. For the CAC 40 firms, individuals are not the largest blockholder, but when they effectively are present as blockholders, they hold around 30\% of the voting rights and have the control in fact' (Bloch and Kremp, 2001, 123). A recent French study by Allouche and Amann (1995) showed that, in $1992,28.3 \%$ of the top 1,000 industrial companies were controlled by families (foreigners $23.5 \%$ and state $28.2 \%$ ). Furthermore, when excluding the state and foreign owned companies from the analysis, families controlled $59 \%$ of the top 500 industrial companies, an increase of $10 \%$ on the 1982 statistics. Blondel, Rowell and Van der Heyden (2002) investigated the ownership structure of France's 250 largest publicly traded companies for both 1993 and 1998. They show that 57\% of the listed SBF 250 companies were patrimonial firms i.e. companies where individuals or families had an ownership stake exceeding 10\%. Furthermore, confirming Allouche and Amann's (1995) results they noted that, rather than being on the wane, patrimonial firms grew from $48 \%$ to $57 \%$ of the SBF 250 over the period 1993-98, Taking all firms listed on the French stock exchanges between 1994-2000, Sraer and Thesmar (2004) observed that approximately a third of the firms were widely held, another third were founder controlled and the remaining third were heir controlled family firms. Their results show that both founder controlled and heir controlled family firms largely outperformed widely held corporations. In December 2002 the business magazine, Le Nouvel Economiste, estimated that the five hundred richest families in France had a fortune of 106 billion euro. Within this group the fifty richest families had assets of 72 billion euro and the ten richest had assets of 43 billion euro. 
Additionally, as distinct from the United States, where there has been a predominantly multidivisional corporate structure, there are many holding-company structures controlling large industrial groups in France. Lévy-Leboyer (1980) explained the development of these holding companies as arising from banking and capital market limitations:

...financial constraints, particularly the inability of the banks and the capital markets to cope with businesses' new requirements, finally brought into being large industrial groups tied together by financial holding companies. (1980, p. 629)

\section{History and Corporate Ownership - An Overview}

History is revelatory in identifying many of the key factors that have produced the current corporate ownership structure in France. Analysing this historical evolution and development is a complex task. Those looking for some type of linear progression with newer institutions building on and evolving from older institutions may be disappointed for the last three hundred years embrace a wide range of diverging tendencies. There are many discontinuities. In this respect the history of corporate finance in France is quite distinct from that of the U.K. In the latter country political revolution, involving warring factions, had ended by the end of the seventeenth century and a significant part of the financial revolution had taken place by the third decade of the eighteenth century. In Britain one can see a type of linear progress as institutions built on institutions. Through the eighteenth and nineteenth centuries British banks and insurance companies became increasingly adept at channelling savings to investors. The stock exchange efficiently raised finance to fund the borrowing requirements of the Exchequer and to provide capital to the trading companies that were extending Britain's imperial and colonial power. The political system hovered around the centre rarely oscillating excessively to the left. Additionally, and importantly, Britain was not invaded.

France was to have a more tumultuous three hundred year history. During the eighteenth century it was involved in a number of long and expensive wars (The War of the Spanish Succession, 1701-14; the War with Spain 1718-20; the War of the Polish Succession, 1733-38; the War of the Austrian Succession, 1740-48; the Seven Years' War, 1756-63; the War for American Independence, 1778-1783; the wars that emerged from the Revolution 1792 to the start of the Napoleonic Wars). It possessed a monarchy until the revolution of 1789 , followed by a revolutionary government until the arrival of Napoleon. From there political life 
experienced the tumult of the restorations of the monarchy and of the Napoleonic dynasty. Add to these the siege of Paris by the Germans in 1870 and the commune in Paris when twenty to thirty thousand citizens were killed in a mini-civil war in 1871 . The German invasion of 1870 was the prelude to two further invasions during the two World Wars of the twentieth century. These political developments frequently meant that industrial developments had to play second fiddle to the political orchestrations of wars, civil wars and invasions. And yet, notwithstanding these developments on the home soil, France became one of the largest colonial powers of the last three centuries ruling sizeable tracts of land in Africa, North and South America and Asia.

Because France was frequently at war, both internally and externally, the political instability of the country was accompanied by financial instability. Wars and revolutions require financing. This financing in turn created significant state borrowing and debt. Perforce the banking system and the capital market were heavily tapped to provide finance for these wars. As a corollary to this the state's heavy recourse to borrowing left substantially less available for the banks and the capital markets to provide to the private sector. The next two sections show the development of (1) the banking sector and (2) the capital market against this background of long periods of warfare.

\section{The Evolution of the French Banking System}

This section highlights three elements in the early development of banking that cast a long shadow over France's financial history. They are: (1) John Law's Mississippi system; (2) the surrogate banking system provided by the French notaires; (3) the assignats experience during the French revolution. It will then show the knock-on effects that these developments had for the banking system in the nineteenth and twentieth centuries.

Renaissance Italy, seventeenth century Holland and Sweden, and, belatedly, England, with the establishment of the Bank of England in 1694, grew through the establishment and development of their respective banking systems. While the English banking system evolved and helped to finance the war against Louis XIV, the French banking system remained underdeveloped to the point that Louis XIV had to rely on the protestant Genevan based bankers - many of whom he had persecuted and forced out of France through the revocation of the Edict of Nantes - to finance a large part of his budgetary deficit. 
The death of Louis XIV essentially left France bankrupt creating an environment in which the Scottish born John Law (1671-1729) could present a new financial architecture aimed at (1) relieving the shortage of money through the establishment of a note issuing bank and (2) reducing the state's indebtedness through the creation of a trading company which would have as one of its objectives the conversion of government securities into equity of the company. Both of these developments were to have a profound effect on banking and the capital markets in France. In the immediate short-term Law's System would make France the most innovative country with respect to corporate financing and banking in Europe. In the long-term it would leave a deep hostility and mistrust towards banks and financial innovation.

The General Bank was established by Law in May 1716 - see Murphy (1997). It was modelled on the Bank of England in that it obtained its banking privileges from the state in return for taking up part of the national debt - part of the outstanding amount of short term billets d'état. The early success of the General Bank enabled Law to embark on the second aspect of his macroeconomic strategy, namely the management of the national debt. To do so he needed to create a trading company modelled on the lines of the British trading companies such as the East India Company and the South Sea Company. In August 1717 he established the Company of the West (Compagnie d'Occident), which was given monopoly-trading rights over French Louisiana - an area representing half of the landmass of the United States today (excluding Alaska). It acquired these trading rights in return for re-structuring, and accepting a lower interest rate, on part of the outstanding amount of billets d'état. The Company benefited in that it acquired rights to exploit the agricultural and mineral potential of this huge area. The state benefited in that part of its floating short-term debt was converted into long-term debt, which bore a lower rate of interest. Shareholders in the new company, who swapped billets d'état in return for the company's shares, had the prospect of large capital gains if the wealth of Louisiana was properly exploited. The nominal value of each share, which came to be known as mères, issued by the Company of the West was 500 livres, but, as they were purchased with billets d'état, then standing at a discount of over $70 \%$, it meant that the initial shareholders purchased their shares at a price of around 150 to 170 livres. It took nearly two years for the shares to reach their nominal issue price of 500 livres.

Initially there was little interest in the Company and Law had difficulty in selling its shares. A year after its establishment Law started to use the Company of the West to mount a series of spectacular takeovers and mergers. At the same time he developed the General Bank by 
ensuring that it was used as the government's bank for the receipt and disbursement of state funds.

In August 1718 the Company of the West acquired the lease of the tobacco farm, while in December it took over the Company of Senegal. In the same month the General Bank's operations were re-organised and it was re-named the Royal Bank. In May 1719 Law merged the enlarged Company of the West with the Company of the East Indies and China to form the Company of the Indies. Further acquisitions in the form of the Company of Africa and the lease of the Mint were made in June and July of that year. These acquisitions and mergers required financing. Law arranged this through the issue of two tranches of shares known as the filles, and petites filles. It has already been shown that the mères, issued in 1717 on the establishment of the Company of the West, were subscribed for in billets d'état, which were standing at a very sizeable discount, effectively costing the first shareholders only 150 livres. The second issue of shares, the filles, were issued in June 1719 at 550 livres. The share price jumped in July enabling Law to issue a further batch of shares, the petites filles, this time at 1,000 livres each.

By the end of July 1719 Law's Company had issued 300,000 shares with a nominal value of 150 million livres. As the share price had jumped from 150 livres in 1717 to over 1,000 in July 1719 , the stage was set for further leverage of Europe's first major stock market boom. This boom was linked to Law's wish to take-over France's national debt by swapping shares for government securities. The sheer magnitude of this operation proved to be breathtaking.

On August 26, 1719 the Regent presented Law's proposal for the Mississippi Company, as it was popularly known, to take over the tax farms and the remainder of the national debt. Law's plan was to lend the King 1.2 billion livres at an interest rate of 3\% so as to repay the national debt. This money would be used to repay the long-term state debts, the annuities (rentes), the remaining short-term floating debt (billets d'état), the cost of offices (charges) that had been or would be suppressed, and the shares of the tax farms.

Under the plan holders of government securities were forced to give up government securities, bearing a $5 \%$ rate of interest, while at the same time they were offered the possibility of acquiring shares of the Company yielding far less in terms of dividend but possessing the prospect of sizeable capital gains. With the share price jumping from 2,250 on August 1 to 2,940 on August 14, to 5,000 and over in mid-September, capital gains rather than dividends occupied the minds of most transactors. By these measures Law proposed 'the radical cure' for the French economy. He aimed to transform the Company from a trading company to a trading- 
cum-financial conglomerate, controlling the State's finances most notably tax collection and debt management.

The sharp price rose sharply during August. On August 1, 1719 the original shares, the mères, which, as has been shown, could have been bought for around 150 livres in 1717 stood at 2,750 livres. By August 30 they had risen to 4,100 and by September 4 they were at 5,000 livres, with the filles and petites filles rising pari-passu. The debt holders recognising the prospect of a capital gain were quite happy to transfer their debt into shares rather than bonds. They needed the prospect of an expected capital gain to compensate for the interest reduction on their securities from $4 \%$ to $3 \%$. Their difficulty in fact became one of converting quickly enough into the shares of the Company as the price of the shares rose very sharply during September.

Within a three-week period in September/October the Company issued 324,000 shares, of which 300,000 were sold to the public at 5,000 livres a share, amounting in all to 1.5 billion livres. The Company had now started to operate in a different manner to that characterising its operations between August 1717 and August 1719 when it raised around 106 million through the first three share issues.

The shares reached a 1719 high of 10,000 on December 2. At this point the market valuation of the Mississippi Company was 6.24 billion livres. Concomitant with these developments the banknote issue of the Royal Bank had been increased from 160 million livres in June to 1 billion livres by the end of 1719 as money was lent to existing shareholders to purchase further shares. France was awash with liquidity, particularly after the Company guaranteed a floor price of 9,000 livres a share in early 1720 through the establishment of a buying and selling agency known as the 'bureau d'achat et de vente'. Effectively, the workings of this agency monetized shares.

In February 1720 the Royal Bank and the Company of the Indies were formally merged together. At this juncture, Law, who had been appointed Controller General of Finances, in January 1720, wrote:

One sees here a sequence of ideas which are interlinked and which reveal more and more the principle on which they are based. (Law, 1934, iii, 98-99)

For a while the System, in all its unifying beauty, seemed to work. Economic activity boomed, the national debt appeared to be under control, money was plentiful and the interest rate had been driven down to $2 \%$. 
Law had created a financial system the long-term viability of which was crucially dependent on the growth of the real economy. There had to be some equilibrium relationship between the financial system and the real economy. For a while a temporary equilibrium existed, as transactors seemed content to remain within the financial circuit trading money for shares, and shares for money. However, once money started spilling too quickly from the financial circuit into the real economy problems arose. The real economy proved to be incapable of generating a sufficient growth in commodities to match the monetary expansion so that the excess money created inflation and balance of payments problems. Law had always believed that the growth in the real economy, spurred on by monetary expansion, would be sufficient to mop up the newly created money. Indeed, in Money and Trade (1705) he went further and argued that monetary expansion would lead to a balance of payments surplus. For a period Law tried to lock transactors into the financial circuit by a series of measures ranging from prohibitions on the holding of more than 500 livres of specie or bullion, to the demonetization of gold and a phased monthly demonetization of silver. Temporarily these measures worked. But there was still too much liquidity in the System. On May 21, 1720 an arrêt was published stipulating that shares were to be reduced by four ninths (from 9,000 to 5,000) and banknotes by half (eg. a banknotes worth 10,000 livres to be reduced to 5,000 livres) between May and December.

This was an attempt to reduce the liquidity of the System thereby bringing the financial circuit back into line with the real economy. Despite the revocation of this May 21 arrêt a couple of days later - due to public pressure - the effect on confidence was so great that the System never recovered from it. The price of shares and banknotes fell continuously during the summer (ironically, at this point the shares in the South Sea were rising rapidly) and the autumn of 1720. Law was forced to flee the country, with the aid of the Regent, in December.

Law had shown that he was able to conceptualize and establish, if only for a short period, a modern non-metallic world at the start of the eighteenth century. He had shown, albeit for a brief three years period, the massive potential of the capital market and the way in which positive wealth effects from this market could drive the economy to greater growth. It would take economists and financial leaders another couple of centuries to produce for the global economy what Law had briefly achieved in France in France during 1719-20. Du Tot realised the full extent of this achievement:

In this state, this construction was admired by everyone in France and was the envy of our neighbours who were really alarmed by it. Its beauty even surpassed all the hopes that had been placed in it since it made people despise and refuse gold and silver. It was 
a type of miracle which posterity will not believe. However, it is clear that there was a period, of many months, when no one wanted them [gold and silver]. (Du Tot, 1935, i, 106)

The failure of Law's System produced a very strong reaction against banks, credit and financial innovation. It also heralded a retour en arrière for the French financial system to the old one dominated by religious directives controlling the methods of borrowing and lending and the state constituting the main borrower of funds through the creation of rentes (annuities). In this strange financial no man's land where interest could not be explicitly charged, contracts had to be drawn up separating the ownership of savings from the streams of revenue it generated. The notaires (notaries) were at the centre of this system. Indeed their role was so central, in the absence of traditional style bankers, that they became surrogate bankers.

\section{$\underline{\text { The Notaires as Bankers }}$}

The credit market in eighteenth century post-Lawian France cannot be interpreted as one in which there was a free flow of funds between surplus and deficit units with the rate of interest acting as an equilibrating factor in the allocation of funds.

The usury laws, allied with the failure of Law's Royal Bank, created an environment in which the standard evolution of banking from goldsmiths to credit creating deposit banks did not take place in France in the eighteenth century. Between 1720 and the Revolution, aside from bankers who discounted bills of exchange - an important media of exchange for merchants much neglected by historians - and one or two scattered sightings of banks such as the short-

lived, Caisse d'Escompte, eighteenth century France existed without a formalised banking structure. While the Genevan based protestant bankers became major lenders to the government and big merchant companies, the question arises as to how the more mundane business of banking was carried out in the absence of clearly constituted banks in France during this century.

Recently Hoffman, Postel-Vinay and Rosenthal (2001) have advanced the thesis that the French notarial system, in particular, the Parisian notaires, provided a sophisticated surrogate banking system. Because of the usury laws they were the intermediaries for every transaction embodying an implied rate of interest as they were the only agents who could notarise financial instruments in the form of obligations, rentes constitutuées and rentes viagères. The analysis of Hoffman et al. shows that the notaires acted as bankers by intermediating as agents between 
savers and borrowers. However, notwithstanding the pervasiveness of their intermediating activities, the notaires were for the most part only demi-bankers acting as a conduit for savers with surplus funds to borrowers, most notably the state. The notaires were usually not principals in these transactions nor did they did act as bankers in the sense of lending credit to some multiple of the funds deposited with them. Furthermore most of the lending activity that they arranged was of a long-term nature. Their banking role was narrowed down further in that most of the lending that they intermediated was to the government on a long term basis through the acquisition of rentes or loans for the purchase of lands or property. Hoffman et al. $(2001,361)$ admit in a footnote that the development of long term credit in both Britain and France initially was more beneficial for the public debt and the housing market than for industry and trade $(2001,361)$. Whatever about the validity of their reflection on the British situation, it is revealing in that it shows that French lending activity was concentrated in two sectors, the state and real estate. The rentier mentality - a natural successor to the earlier financier mentality - has deep roots in French history.

The thesis of Hoffman et al. is that the notaires provided a type of golden age in banking acting as highly efficient intermediaries between savers and borrowers. Their information base - they were able to pool and share information up to the early part of the nineteenth century provided detailed knowledge on the assets of borrowers and whether they were encumbered or not. This information enabled them to provide high quality borrowers for savers with surplus funds. The utilisation of this information provided a stable background for lenders in which there was a low risk of default. This stability in turn generated confidence in the system and increased the number of lenders prepared to act through the notarial system.

An alternative interpretation is to view this surrogate banking system as costly, highly conservative and inefficient because of the additional complication that the usury laws prevented the rate of interest from allocating credit between savers and borrowers. The notaires operated a highly effective cartel. In 1659 there were 113 notaires in Paris. Despite the growth of Paris the number of notaires remained the same until they rose to 122 in 1859 ! The system was costly in that transactors were subject to notarial fees and excluded from the market if they did not have appropriate asset backing. The usury laws, which set a ceiling rate of interest of $5 \%$, effectively ensured that the notaires faced with excess demand for credit could filter out borrowers by the value of their asset collateral rather than the quality of the intended investment project. The system was conservative in that the vast bulk of lending was to the government and property sectors. Incipient industrialists would have found it practically 
impossible to borrow through the notaires. Above all it must be pointed out that the notarial system was not a banking system in the sense of providing a flexible structure for the expansion of credit. All the notaires did was to increase the velocity of circulation of money by making it easier for some borrowers to access savers. However, they were not principals in the financial transactions and were in no way capable of lending money against reserves deposited with them.

\section{The Assignats Experiment}

The revolutionaries were quick to recognise the strait-jacket of the Ancien Régime's financial system. In October 1789 they repealed the legislation that criminalized the stipulation of a rate of interest on a contract. In July 1796 they abolished the ceiling rate of interest. Between these two dates they set up a paper money system. The revolutionaries, copying in many respects Law's earlier theoretical plans for a land bank in Scotland, financed the early stages of the revolution through the issue of the assignats, a paper money initially assigned, or, collateralized, by confiscated ecclesiastical property. When first issued through a decree of December 19, 1789, the assignats bore a rate of interest of five per cent. The interest payments were quickly stopped and the assignats were transformed into fiat money in 1790. The creation of the assignats produced heated debate in the French Assembly with partisans of the System maintaining that they were not inflationary financial instruments because they were fully backed by the confiscated ecclesiastical property. Other parliamentarians tellingly reminded their listeners of Law and his System. Though seventy years had elapsed between the end of Law's System and the Revolution, the memories of Law's attempted financial revolution were still fresh in the minds of those sitting in the Assembly. Indeed, John Law was the most cited economist in the debates that took place in the Assembly on the assignats. In September 1790, the Abbé Maury held up a fistful of banknotes in the Assembly remarking:

Alas! At this moment I hold in my trembling hands many of Law's banknotes, these fictive pledges of an immense and illusory capital, which I drew from a huge depot where they have been held for the instruction of posterity. With sorrow I look at these paper instruments of so many crimes, I see them still covered with the tears and blood of our fathers and I offer them today to the representatives of the French nation as beacons placed on the reefs so as to perpetuate the memory of this massive shipwreck. (Archives Parlementaires, vol. 19, September 28, 1790, 300) 
Maury's melodramatic warning words were not accepted. The assignats were much needed to finance the early stages of the Revolution with Harris contending that they kept fourteen armies in the field $(1930,53)$. They were first issued on April 1, 1790 for a total of 400 million. By September 1792 they had risen to 2.7 billion and a year later that were over 5 billion. By March 1795 they had reached 8 billion rising to 20 billion in the same year. When they were eventually taken out of circulation in 179645.6 billion had been issued of which 32.8 billion were still in circulation (Lafaurie, 1981, 169). The over-issue of assignats led to massive hyperinflation. Taking a price index of 100 in January 1791, White (1989) showed that it rose to 30,411 by March 1796 ! Kindleberger concluded that the assignats '...embedded paranoia about paper money and banks more deeply in the French subconscious, and helped establish Napoleon successively as consul and emperor.' $(1984,99)$

It was not until 1800 that a quasi-central bank, the Banque de France was established and even here the primary reason for its establishment was to lend money to Napoleon's government. Additionally, jealous of its monopoly issuing powers, the Banque de France spent its first fifty years trying to block the creation of other banks. The massive difference in progress between the British and French banking systems may be seen by reading Henry Thornton's An Enquiry into the Nature and Effects of the Paper Credit of Great Britain (1802) on the role of the paper credit system in Britain. Thornton, a professional banker, attacked Adam Smith for his lack of understanding of the extent to which banknotes and bank credit had become central to the financing of the British economy. He showed the sophisticated layers of different types of paper credit that had been introduced in Britain to finance economic activity and the central role of the Bank of England in the provision of credit. The London banks depended on the Bank of England and the country banks in turn depended on the London banks. Furthermore, Thornton showed the ways in which the Bank of England could improve its function as a lender of last resort to the banking system. Thornton's analysis demonstrated that Great Britain had a far more sophisticated banking system than that of France with the Bank of England acting as a quasi Central Bank, all this at the very time that the Banque de France had just been established!

The hyper-inflationary experience of the assignats, reinforcing the earlier collapse of Law's System, strengthened a strong anti-banking and financial innovation view in France. It intensified the French public's bas de laine mentality i.e the hoarding of gold and silver in woollen socks underneath the mattress. Not only did the French hoard gold and silver, but, they also used specie as the main medium of exchange for most of the nineteenth century. This 
strong preference for specie meant that it constituted $95 \%$ of the money supply in $1803,82 \%$ in 1845 , and $68 \%$ in 1870 . By 1885 it still amounted to over 52\% of the money supply (Cameron, 1967, 116). Flandreau (2004) has recently shown that, notwithstanding the growth of banking in the north-eastern half of France in the 1850 s, specie holding greatly increased across the country in that decade due to a combination of factors - the growth in farm incomes, the absence of a banking network in country areas and the inflow of new supplies of gold from the Californian Gold Rush. The French love of gold continued through to recent times as evidenced by the reporting of the daily price of small gold bars (les lingots) and gold coin (le Napoleon) alongside news of stock price movements on radio and television.

The vesting of significant monopoly powers in the Banque de France, along with the extensive use of specie as a circulating medium, meant that the banking system remained underdeveloped for the first half of the nineteenth century. This view runs counter to that developed by Lévy-Leboyer in Les Banques européennes et l'industrialisation internationale dans la première moitié du XIX siècle (1964). In this work Lévy-Leboyer concluded that, contrary to conventional opinion, the banking system was highly effective and that by 1843 'the financial market gave the impression of having become the living part of the economy' $(1964,699)$. However, a couple of pages later, Lévy-Leboyer equivocated with respect to this strong conclusion admitting that, aside from Paris, it was financial centres outside France, based in Geneva and Basle, that provided banking facilities for the merchants of Lyons and Mulhouse. Lévy-Leboyer equivocated further by admitting that:

It should not be forgotten that, in many regions, credit was unheard of: in the countryside, the usage of banknotes continued to be unknown; in the manufacturing towns bills of exchange were continually used for ordinary transactions, and in most cases, even in Alsace, those wishing to borrow money were obliged to go to the notaires (there were nearly 10,000 in France in 1840) or to less recommended business agents $(1964,705)$.

This latter description, showing the continued use of notaires, does not suggest that there was a highly effective banking system in France at the time.

There were still considerable constraints preventing the emergence of a proper credit based banking system. How could a paper based media of exchange system emerge when, up to 1847 , the smallest denomination note of the Banque de France was 500 francs? This, as Cameron $(1967,117)$ has pointed out, was greater than the annual per capita income in France at the time. How could a credit creating banking system thrive when the currency (i.e. gold and silver 
coins) to deposits ratio was so high? Furthermore the Banque de France systematically blocked the emergence of other banks in order to maintain its monopoly banking powers. It was not until 1848 that legislation was introduced to charter joint-stock banks. The change in legislation enabled the Pereire brothers to establish the Crédit Mobilier in 1852 and in that same year the Crédit Foncier, which in turn established the Crédit Agricole and the Comptoir de l'Agriculture as subsidiaries, started business. In 1859 the Crédit Industriel et Commercial was created while in 1863/64 the Crédit Lyonnais and the Société Générale were established. Notwithstanding the creation of these banks, cheques were not legally recognized until 1865 and the public still had a strong bias in favour of specie. Cameron concluded on the French banking system up to 1870:

Comparisons with English and Scottish data reveals that the complaints of French businessmen were justified: bank facilities were too few, and bank resources pitifully inadequate. At the end of its 'take-off' period the French economy had approximately the same bank density as Scotland had had in the middle of the eighteenth century. France had fewer bank assets per inhabitant in the mid-nineteenth century than England or Scotland had had in 1770 and in 1870 had not reached the position that they had held before the beginning of the nineteenth century' $(1967,110)$

Furthermore it continued like this with specie still constituting the preferential form of money up to World War 1. By 1913, despite the expansion of bank deposits from $17.2 \%$ in 1880 to $44.3 \%$ of M1 defined as coin, banknotes and bank deposits, they still constituted only a small part of the overall money supply. In the U.S. and U.K. bank deposits represented about $88 \%$ of M1 at this point in time. This conservatism with respect to deposit creation had its counterpart in the area of credit expansion.

Gueslin observed that between the 1880 s and 1930s companies had to rely on self-financing rather than bank credit ' ... banking credit remained more or less limited and the financing of the economy came about through the accumulation of savings: primarily as companies directly used parts of their cash flow, but also by the transfer of domestic savings via the financial market' $(1992,63)$. This meant that the banking sector, despite its expansion in the middle part of the nineteenth century, continued to play a predominantly conservative role in the extension of credit to the industrial sector.

Between the two World Wars the relative imbalance between the development of banks in France and in Great Britain and the U.S. was very great. One indicator of this was the size of bank deposits per head of the population. Gueslin noted that in 1937 per capita bank deposits 
amounted to 1,700 francs in France as against 12,000 francs per inhabitant in the U.S. and 10,100 francs in the U.K.

The apparent backwardness of France can be explained by the lesser importance there of bank deposits, the existence of channels for financial savings, the competition of the savings banks ... and by the probable existence of hoarding, reflecting the still essentially rural nature of the country (Gueslin, 1992, 87).

In Gueslin's view 'It was only after 1966, and not without difficulty, that the commercial banks of France were really able to flourish'. The road, from John Law's Royal Bank in 1720 to an efficient commercial banking system in France in 1966, had been a long one.

\section{Capital Market Developments}

As has been shown, over-borrowing by Louis XIV left France effectively bankrupt and created the conditions for John Law to embark on the most dramatic macroeconomic and corporate financing experiments of the eighteenth century. The apparent success of his Mississippi System showed the potential for an economy to operate without metallic money and to innovate with respect to re-structuring the national debt. Fears that Law had discovered the Philosopher's Stone led the British to follow suit and use the South Sea Company to restructure the public debt. The strong anti-banking mentality that arose from the collapse of the Royal Bank in 1720 was accompanied by a strong official reaction to joint stock companies. Again the events of 1720 were central to this reaction. Ironically, in a bid to corner the market for loanable funds, the South Sea Company pressurised the British government to introduce the Bubble Act of 1720. The Act nullified bubble companies that had been established without joint stock charters from Parliament. It backfired in the face of the South Sea Company, for, in precipitating a collapse of the smaller bubble companies, it forced holders of such fallen stock to sell South Sea in order to pay for these losses. These sales in turn caused the price of the South Sea Company to collapse. The far greater consequence of the Bubble Act was that it effectively prevented most British companies from obtaining joint-stock charters for more than a century. This remained the situation in Britain until the repeal of the Bubble Act in 1825 and the introduction of the Companies Act - popularly known as the Limited Liability Acts - in 1862.

It was a similar, if not longer, story in France. From 1721 onwards, due to the collapse of Law's Mississippi Company, it was particularly difficult for companies to obtain full limited 
liability status. Investors, wishing to form joint stock companies, could only do so by acquiring permission from the government and undergoing a cumbersome process of establishing their charters through complicated legal procedures. Through the eighteenth and the first half of the nineteenth century French jurisprudence confined, all but a restricted number of companies in areas such as insurance and transportation, to two legal structures:

(1) Simple partnerships (Sociétés en nom collectif)

(2) Limited partnerships (Sociétés en commandite)

In the simple partnerships all partners were equally liable for the firm's debts. In the case of the limited partnerships the 'sleeping partner' (the commandite) who subscribed the capital only risked the amount that he subscribed, whereas the active partner or partners assumed unlimited liability. For example, the Irish born economist Richard Cantillon, who made a fortune out of the Mississippi System, ensured that he was the 'sleeping partner' in his bank in 1718-1720 so that his liability was limited to the capital that he subscribed. (Murphy, 1986)

The simple and limited partnerships were unsatisfactory corporate structures for the development of large sized companies. Many owners and managers did not want to face the problem of unlimited liability. Additionally, there were very high transaction costs for partners wishing to withdraw their capital. Say and Chailley summarised the problems with this system:

This was really a deplorable system because of the slowness that it entailed in the establishment of companies, because of its arbitrariness, and because, in the case of bankruptcy, shareholders blamed the government, and, believed themselves entitled to demand it to compensate them for their losses (1892, ii, 887).

Lévy-Leboyer noted that the Council of State, to which companies had to submit their plans for going public, instead of helping the formation of share issuing companies ' ...continually looked for ways of increasing its own powers without regard for the companies that it discredited nor for the economy the expansion of which it braked' $(1964,702)$.

Cameron contended that "the depression of 1857 revealed the undesirability of excessive reliance on the commandite form of organization for large-scale industry and commerce' (1967, 109). The Council of State started to liberalize its approach to company incorporation. The change in the British legislation in 1862, along with the incipient financing needs of the newly created railroads, further increased the pressure to change which started in 1863 and continued through the introduction of the Limited Liability Acts (Loi sur les sociétés) on July 24, 1867. This Act ensured that companies could be established freely under a limited liability charter without having to seek the formal and costly authorisation of the Council of State. The new act 
encouraged the growth of limited liability companies, but, the ability of these companies to tap the capital market was constrained. Aside from the railway companies, domestic French companies had difficulties in initially attracting French investors. Lévy-Leboyer has focused attention on the relative immaturity of capital markets in France as against those of the U.S. and U.K. in the latter part of the nineteenth century and the first decades of the twentieth century. This lack of maturity prevented mergers developing to produce growth in the industrial sector. He observed:

Before 1913 and during World War 1, the volume of security issues and the number of mergers remained rather low-probably because of a widespread prejudice against industrial shares and the lack of experience in marketing these securities on the part of banks and brokerage houses, which had previously dealt primarily in railroad bonds, public utilities and foreign securities. $(1980,600)$

In pre-World War I France there was a tendency on the part of French people to invest in government bonds or foreign securities rather than in equities. A German remarked at the time 'If they do not succeed in changing the attitudes of the higher classes of the population, then nothing will stop France from becoming a nation of rentiers. The organization of her banking system is well designed to produce such an outcome' (Gueslin, 1992, 72). Pollard (1985) has shown that in 1870 over a third of French domestic savings were invested abroad and by 1910 this figure had risen to over 50\%. The oral tradition in France provides many stories of ancestors who lost fortunes in railway shares and loans to Russia and other eastern European countries. Trunks full of these useless shares and bonds are to be found in family attics and in junk shops.

Bonin, writing of the Belle Epoque period from 1895-1914, noted that the majority of companies '...remained hostile to external capital, to increases of capital, to borrowing and to the banks. Self-financing dominated (two thirds in 1913) due to profits, the quick amortization of capital expenditure, financial reserves and a treasury the abundance of which was revealed by the expansion of bank deposits' $(1988,40)$. Using Teneul and Lévy-Leboyer's estimates Gueslin concluded that'...even if there were some exceptions, most investment on the eve of the First World War did come from undistributed profits'. $(1992,81)$ So self-financing was the norm for French companies. Notwithstanding Gueslin's conclusion Rajan and Zingalese (2001) have recently presented statistics indicating that, on the eve of World War 1, France had a relatively high stock market capitalisation/GDP ratio of .78, double that of the U.S. (.39) and not too far from that of the U.K. (1.09). However, this statistic appears to be very much an 
outlier as the stock market /GDP capitalisation statistics for the rest of the twentieth century produced by Rajan and Zingalese (2001: 61) show:

$\begin{array}{cc}\text { Year } & \text { French Stock Market Capitalisation/GDP } \\ 1939 & 0.19 \\ 1950 & 0.08 \\ 1960 & 0.28 \\ 1970 & 0.16 \\ 1980 & 0.09 \\ 1990 & 0.24 \\ 1999 & 1.17\end{array}$

So, while it appears that the French briefly flirted with the stock market in the first decade of the twentieth century, this flirtation, unlike the U.S. and the U.K., did not persist through the twentieth century. The statistics for 1999, most probably reflecting the privatisations of major French companies in the 1980s and the rise in their market value in the 1990s, show some revival of interest.

\section{Conclusion on Historical Elements influencing Corporate Ownership}

By this stage some the main themes of this paper have started to emerge. For a great part of its three hundred year history since the rise and fall of John Law's Mississippi System, France has been underbanked and has had a weak capital market. Unlike Great Britain, where the Bank of England was not brought down by the fall of the South Sea Company, the stock market crash of 1720 involved the complete destruction of the Royal Bank's banknotes and confidence in the banking system. The collapse of the fiat money system created considerable hostility to banks, credit and financial innovation. This anti-banking mentality was later exemplified in Turgot's magnum opus, Réflexions sur la formation et la distribution de la richesse (Reflections on the Formation and the Distribution of Wealth), first published in 1769/70. In the Réflexions Turgot introduced the concept of capital into economics for the first time and showed the link between savings and investment in the generation of economic growth. The work was to have a profound influence on the theory of capital formation in the $19^{\text {th }}$ century. Yet, for all its brilliance, Turgot missed out because his analysis on the process of capital formation was 
confined to the time warp of eighteenth-century France, an economy in which banks did not exist and in which the capital market was the exclusive preserve of the government. Turgot maintained that savings financed investment and that savings were generated by abstention from consumption expenditure. He saw no role for the banking system in this process of capital formation. There is no mention of the words bank or credit in the Réflexions! Thus, we are left with the paradox that one of the outstanding economic works on capital formation has only a very elementary link with modern works on corporate finance because it is based exclusively on an internal financing model.

Turgot's strong antipathy towards banks, which started, when, as a young seminarian at the Sorbonne, he pilloried John Law and his System (1749 [1913, I]), was symptomatic of eighteenth-century French attitudes towards money, banks, credit and financial innovation. Add to this antipathy, the hyperinflationary experience created by the assignats, and the French public's desire to use specie rather than money created by banks becomes clearer. The heavy reliance on specie as a medium of exchange made it difficult for banks to emerge. In turn their ability to expand credit was limited by their difficulties in building up sufficient reserves of specie to create deposits. This view ties in with that of Kindleberger who maintained that '...France lagged behind Britain in financial institutions and experience by a hundred years or so..." ((1984: 113). This is not to say that there were no banks operating in France in the first half of the nineteenth century but that their influence was relatively weak. Even the "haute banque' which started to pioneer the art of merchant banking in the early part of the nineteenth century was so 'haute' that it did not cater for most of the emerging industrial sectors. It concentrated on investments in the railways, real estate, public works (roads, bridges, canals) and insurance. The Crédit Mobilier, a bank established by the Pereire brothers in 1852, was an attempt to find more broadly based support from stock market investors. It competed with the 'haute banque' by investing in public works and railways not only in France but across the European continent. Its collapse in 1867 along with the later collapse of the Union Générale, which lasted a mere four years from 1878-1882, reinforced French attitudes on the riskiness of banks.

Meanwhile the stock market, aside from financing the government, had difficulties in generating equity issues because of the legal restraints that prevented the creation of limited liability companies up to 1867. Even after this companies did not use the capital market intensively. A great deal of the later nineteenth century French investment in the stock market was in railway stocks and foreign investments. 
A second historical element that is important in the French case relates to the role of inheritance law. Napoleon, when he introduced the Code Civil, moved the inheritance system from one based on primogeniture to a new system based on equal rights for all the children in a family. This change is important to note in that, unlike the U.S. and the U.K., where a testator can leave his/her estate to a charitable foundation this is not possible in France. The children are stakeholders in the parents' estate. So, almost by definition, the family, due to the inheritance laws, becomes a major player in the ownership of French corporations. The only way to keep the family out of the corporation is to sell the company prior to death and spend the proceeds. As the French have lived through three German invasions in the last one hundred and forty years, few of them are inclined to spend all of their wealth on current consumption because of the fear that they may face the days of the 'vaches maigres' prior to death. Furthermore, in order to prevent the state appropriating the family estate through death duties, parents frequently transfer assets from the older to the younger generation via trusts (les indivisions) that give the parents the usufruits of the assets while bestowing on the children the nominal ownership of these assets. Thus, at the death of the patriarch or matriarch, there is only a small part of the estate that may be subject to death duties. Additionally, a change in the inheritance laws in 1905 stipulated that estate duties would only be payable on the net rather than the gross estate. This sent out a clear signal to the owners of wealth to shift from equity financing to loan financing because the latter could be used to offset their gross wealth position whereas the former method would add to overall tax liabilities for their offspring. The French are also very adept at using insurance policies on the lives of the older generation to provide tax free money to cover any death duties that may arise on the estate at inheritance. Combine these elements with a different cultural approach which sees property as part of the 'patrimoine' and that the perceived obligation of property holders is to pass on the 'patrimoine' in a better state to future generations the reason why there is a high degree of concentration of ownership of corporations by families in the French model may be understood. Against such a background, it is not surprising to find family ownership, often concealed through a wide network of holding companies, exercising such a significant role in France's corporate ownership structure.

Finding companies that span the three hundred years that we are investigating which might fit this particular historical template is a difficult task. It is the nature of companies to rise or fall, to be taken over or merged. Few remain in the same direct ownership over a prolonged period of time. One company that remained in the same family ownership for the period investigated was the printing and publishing company, Didot, which later became Firmin-Didot. Founded in 
1698 it remained in business for three hundred years. It was a major book publisher, it was the company that printed the assignats during the Revolution, and it was a publishing house always to the fore in the area of printing technology - it was the first to introduce, for example, the Stanhope press in France in 1818 (Jammes, 1998). Throughout its long history the predominant form of financing for Didot was through the use of retained profits. Even when it issued shares it was only to family members for the purpose of facilitating the transfer of ownership from one generation to another. Blondel and Van der Heyden (1999) examined another family with a long history of corporate ownership, that of the Wendel family, involved in iron and steel production, which was founded in 1704.

Three companies with a strong family involvement and a corporate history spanning a hundred years or more have been selected to show the importance of self-financing in the evolution of their corporate histories. Each of these companies started with simple products, a rubber ball, a hair dye and a pepper mill. From these simple origins they developed into global companies in which descendants of the founders still have very sizeable holdings and representation in the management and direction of the companies. The companies are Michelin, L'Oréal, and Peugeot (PSA Peugeot Citroen). A sample of three does not prove the thesis of this paper. However, it is believed that these three companies are illustrative of a trend in French corporate life where family ownership is still so strongly embedded. They are also three of the most powerful and profitable French companies, employing a total of three hundred and seventy thousand workers.

Because they have been family owned and controlled companies it is difficult to penetrate into the decision making of these companies. Families are discreet and, in many cases, reluctant to open their archives to the public. An alternative method is to side-tunnel into the activities of these companies by examining the archives maintained on them by one of their bankers, the Crédit Lyonnais. These archives show the assessments of this bank's financial analysts towards these companies over a long period of time. They constitute an invaluable, and much underutilised, source into decision making across all sectors of corporate France over the last one hundred and fifty years. Loubet (1999) has edited a range of archival extracts specifically related to the links between the automobile industry and the bank. 


\section{MICHELIN}

Michelin is Europe's biggest manufacturer of tyres. It employs around 128,000 workers who produced sales of 15.7 billion euro in 2002. The history of Michelin traces back to 1829 when a young Scotswoman, Elizabeth Pugh Barker, a niece of the Scottish scientist Charles Macintosh, married Edouard Daubrée. The new Madame Daubrée used the vulcanised rubber solution, discovered by her uncle, to make playing balls for her children. The use of rubber in this way attracted the attention of two of her husband's cousins, Aristide Barbier and Nicolas Edouard Daubrée. In 1832 they established a small factory using vulcanized rubber products for the manufacture of seals, belts, valves and pipes that could be used in agricultural machinery. In 1889 André and Edouard Michelin took over their grandfather, Aristide Barbier's agricultural equipment business. Edouard Michelin diversified the business into the manufacture of tyres and managed the company for the next fifty years. He was assisted by his brother, André, a marketing genius, who promoted the company in its early days via schemes such as the sponsorship of motor car races where the entrants were obliged to use Michelin tyres, the identification of these tyres with Monsieur Bibendum, a caricature of a rotund man made of tyres, and through the creation of the Michelin Guide Rouge, a publication that later developed into a gastronomic guide with its use of the star rating system for restaurants. The combination of Edouard's managerial and engineering skills along with André's marketing flair enabled Michelin to develop from a small-scale artisan enterprise to becoming an international tyre manufacturer. By the time of Edouard's death in 1940 he had built Michelin into a company employing 25,000 employees. Today the Michelin family is estimated to own 25 per cent of the company and its wealth in 2002 , has been estimated at 1.1 billion euro.

How has the Michelin family kept such a sizeable amount of the ownership of the company? The first point to note about Michelin is its rather unusual corporate status in that it is still a partnership (commandite) but with the capacity to issue shares. Because of its partnership status the Michelin family members who are involved in this partnership are liable for the company's debts in the case of a bankruptcy. On the other hand the partnership gives the family control over the company. The family has been able to maintain this position through reliance on selffinancing. From its very inception self-financing appears to have been the mot d'ordre of the Michelin family. When Edouard assumed control of the company in 1886, he turned to the

family rather than to the banks in order to provide the much-needed finance for new capital 
expenditure. He went to his aunt, Emilie Mage, and asked her if she could lend the company a sizeable sum of money, the equivalent of 1.3 million euro. She asked Edouard to wait for a day. Then, having clarified with some nuns, the Petites Soeurs des Pauvres, that they would offer her a room in their convent, if she became destitute due to the non-payment of her loan, she lent Edouard Michelin the money which helped turn the company around (Lottman, 1998). Family ties can run deep at moments of crisis!

The nature of Michelin's business was transformed as it moved into the manufacture of tyres for automobiles. Keeping up production with the growth of the automobile market meant that the company had considerable financing requirements. The family met these financing requirements by ploughing back retained profits into capital expenditure. When these profits were insufficient to meet their capital requirements they resorted to long-term bond issues. This in turn caused problems for their bankers because of their limited access to information on the company's balance sheet. In 1930 when Michelin was seeking a loan of 200 million francs the analysts of the Crédit Lyonnais attempted to uncover the financial situation of the company so as to determine whether the bank would provide some of the capital required. It is obvious from reading the analysts' report of May 1930 that it was difficult determining the profitability of the company, which, because of its partnership status, was not obliged to publish any public accounts. The analyst did provide the following for the period 1925-28:

End year $\quad$ Profits Distributed $\quad$ Amounts put aside in Reserves

Francs millions

$1925 \quad 29 \quad 29$

$1926 \quad 31 \quad 126$

$1927 \quad 58 \quad 58$

$1928 \quad 60 \quad 60$

Assuming that the banking analyst had access to part of the company's accounts - although he did state that he did not know how this 'réglement de l'exercice' had been compiled - the above statistics show that Michelin appeared to have had a policy of retaining a very significant amount of its profits. The retention rate amounted to $50 \%$ of its profits in the years 1925,1927 and 1929. In 1926, on the back of very significant growth, it retained 126 million francs of its profits, over four times the amount it retained in 1925. The analyst concluded that 'the 
development of the business has been made almost exclusively by recourse to retained profits and the management appears to be very prudent'. (CL 4908/3, May 1930, p. 7)

By this stage Michelin, still a family business ('une affaire de famille') had become the dominant manufacturer of tyres in France - its main factory at Clermont-Ferrand was producing 4 to 5 million tyres annually - and it was exporting more tyres than its competitors in the United States.

In 1930 it was successful in borrowing 300 million francs at 4.5\% repayable from 1931 to 1960. In 1946, with its main factory at Clermont-Ferrand badly damaged by Allied bombing, Michelin went back to the banks with a request to borrow 500 million francs. The banking analysts threw their hands in the air in trying to make sense of the accounts provided The 'réglement de l'exercise' which had shown results of as high as 126 million francs in 1927 had dropped to 6 million in 1934 and then risen to a high of 40 million in 1939! Because of the lack of knowledge on the distributions of profits to the shareholders and the management the balance sheet was impossible to decipher properly.

The extent of Michelin's recourse to self-financing may be seen from a further report by the Crédit Lyonnais in 1959 when Michelin was contemplating an issue of bonds to help finance its long term investment. The investment programme envisaged expenditure between 1958 and 1963 of 55.4 billion old francs. Of this sum $75 \%$ was to be met by self-financing.

Again, in 1972, when Michelin decided to expand its North American plants to produce radial tyres, $\$ 250$ million of the $\$ 400$ million investment came from their reserves while the other $\$ 150$ million came from a group of New York based banks (Lottman, 1998, 403).

The second key factor in maintaining the Michelin family's control over the company was through the use of dual-class shares. Control of the company was kept in the family through the use of the partnership's shares and strict rules as to who could hold these shares. In 1928 these rules stipulated how shares would be kept in the family:

...they [holders' shares] may be passed on to descendants or their relations up to the fourth degree [of consanguinity] or to someone who is already a shareholder. In all other cases the transfer is subordinate to the agreement of the Inspection Board and its managers, and, in default of this agreement, to the right of preemption that is formally reserved to the other shareholders. (CL, 4908/3, Mai, 1930)

With respect to the ordinary shares of the company the articles of association stipulate that shares held for more than four years by residents of a country within the European Union have double voting rights. 


\section{L'ORÉAL}

L'Oréal, one of the leading fashion and cosmetics manufacturers in the world, was listed by the Wall Street Journal as the seventy first largest global public company ranked by market value ( $\$ 47$ billion) at the end of August 2003. In 2002 with a labour force of nearly 50,000 it had sales of $\$ 15$ billion. The origins of L'Oréal trace back to 1909 when a simple partnership trading as Schueller and Spery was established to sell a newly created synthetic product for dyeing hair. Eugène Schueller, a chemist by training, manufactured the hairdye in his home and sold it under the brand name Auréole. The name of the company summed up its activities, the French Company for the Harmless Dyeing of Hair (La Société Française de Teintures Inoffensives pour Cheveux). Starting with a capital of 135,000 francs it was transformed into a limited liability company (société anonyme) in 1939 by a merger with Foncière Driant under the name Société 1'Oréal. The new company had a capital of 7 million francs. In 1950 it merged with Monsavon, a company that it would later sell to Procter and Gamble. In 1953 its turnover was 60 million francs with net profits of 1.85 million. Over the next fifty years it grew at a very fast pace so that by 2002 it had net profits of 1.2 billion euros. This performance has made it one of the outstanding shares on the French stock exchange.

With such a sizeable growth it might be natural to expect a wide diffusion of ownership of the shares of the company. This is not the case with closely held shares accounting for 352 million of the 655 million shares outstanding. Its founder, Eugène Schueller, and more recently his daughter, Ms. Liliane Bettencourt, since the death of her father in 1957, have been the major shareholders. In 1967 analysts at the Crédit Lyonnais estimated that Madame Bettencourt owned over 50\% of the capital of the company (CL Etude 9011/4, February 9, 1967) at a time when its turnover amounted to about 295 million francs and its market capitalisation was 528 million francs. In 1974 she sold nearly half of her L'Oréal stock to the Swiss multi-national Nestlé, combining with the latter to establish a French holding company, Gesparal which owns $54 \%$ of L'Oréal. Madame Bettencourt and her family currently own 51\% of Gesparal with Nestlé controlling the other 49\%. So although Madame Bettencourt's ownership of L'Oréal has been reduced, she still has over twenty five per cent of a far larger company. Effectively, through the link with Nestlé, Gesparal can ensure that no corporate predator takes over L'Oréal. The French business magazine, Le Nouvel Economiste, valued Madame Bettencourt's fortune at 13.7 billion euro in 2002 making her the richest person in France. 
It was not always plain sailing for L'Oréal. In the early 1950s it was regarded as a poor credit risk for long-term lending and the difficulty the company had borrowing from the banking system at this stage in its development may be observed from the caution that its bankers had lending it money in 1951 shortly after its takeover of Monsavon. At that time the conclusion of the Crédit Lyonnais' analyst was:

A slowing down of its sales could quickly place the Company in difficulties: this slowdown has already manifested itself for some of the Oréal lines (permanent waves, hair dyes, Ambre Solaire, shampoos, etc.). The Company has announced some cutback measures: reductions in seasonal employments, and a cutback of $20 \%$ on the publicity budget but overhead costs have not been noticeably reduced, the Company contending that the two merged businesses cannot use the same sales representatives and that reductions in the advertising budget will take time. (CL, 5 July 1951)

The analyst was obviously intrigued as to how a company could boil and filter 'tallow $(60 \%)$, palm oil (20\%), the residual elements of pork butcher's meat (10\%) and horse grease (10\%)' into soap and sell it as a quality product. He expressed misgivings as to the amount spent on advertising - a sine qua non of the cosmetics business - commenting on its 'flashy publicity' ('une publicité tapageuse'). He recommended that the bank should be prudent and only lend to L'Oréal on a short term rather than a long-term basis.

Faced with conservative bankers who found it difficult to detect the growth of a business in this dubiously perceived area of ladies fashion ('la mode féminine') the Schueller/Bettencourt family concentrated to a significant extent on self-financing to meet its capital expenditure requirements. In May 1971 another analyst emphasised the extent of this self-financing and the company's low level of indebtedness:

For the period 1971-74 the group l'Oréal has an important investment programme amounting to a total of nearly 330 million francs. Its financing will be easily assured by the recent borrowing of 75 million francs and by self-financing (depreciation + retained profits 1970: about 81 million francs). No numerical increase in capital is expected, particularly because the level of indebtedness is only about 30 per cent of the group's permanent capital. (CL Etude 9011/8, 26 Mai, 1971).

The reliance on self-financing provided L'Oréal with a strong balance sheet that enabled it to borrow long-term from the banking system to finance new acquisitions. By the 1970s 'ladies fashion' had become recognized as a very strong growth market and L'Oréal was well positioned to become the global fashion leader that it has since become. 


\section{PEUGEOT}

Peugeot is the leading French constructor of automobiles. It is the second largest automobile company in Europe. In 2002 it employed over 190,000 workers and produced sales of 54.4 billion euro. Peugeot, as a family controlled company, has had a long and fascinating history. The origin of the Peugeot manufacturing dynasty stretches back to the water mill construction business of Jean Pequignot Peugeot in the eighteenth century. An ability to adapt to new trends and technologies has always been the hallmark of this family. In 1815 the brothers Jean-Pierre and Jean Frédéric Peugeot teamed up with Jacques Maillard-Salins to run a steelworks and a saw blade factory in the area of Montbéliard. The establishment of the saw blade factory was helped by loans from Swiss bankers in Basle - see Lévy-Leboyer (1964, 349). In 1842, JeanFrédéric invented the peppermill, still an essential element of the average kitchen. But this was only one of many ironmongery objects that the company specialized in. Saws, razors, sewing machines, clocks, stays and hoops for crinoline skirts etc were produced in the factory. Its ironmongery experience led to it producing the spokes of bicycle wheels and this in turn led to it becoming the biggest bicycle manufacturer in France. Bicycle production in turn led to automobile production.

In 1896 Armand Peugeot established the 'Société Anonyme des Automobiles Peugeot' despite the misgivings of some members of the family who refused to allow him to use the Peugeot 'lion' logo for a further fourteen years. The nominal capital of the company was 800,000 francs divided into 800 shares of 1,000 francs each. 350 shares were granted to Armand Peugeot as a payment for 'his contribution in bringing in the factory at Audincourt, the patents, cars in the process of production, leases, etc' (CL November, 1908). In 1898 the nominal capital was increased to $2,400,000$ francs through the creation of another 1,600 shares of 1,000 francs each.

This increase in capital was to help finance the establishment of a new factory at Lille. By 1900 Peugeot was producing the Peugeot Phaeton Type 28 with a speed of 35 kilometres an hour. Over its first ten years the company's balance sheet showed losses alternating with profits as the technology of the automobile industry underwent sizeable transformations as the following table, compiled by a Crédit Lyonnais analyst, shows:

$\begin{array}{ll}\underline{\text { Year }} & \text { Francs } \\ 1896 / 7 & -53,000\end{array}$




$\begin{array}{rr}1897 / 8 & 169,000 \\ 1898 / 9 & 360,000 \\ 1899 / 0 & 532,000 \\ 1900 / 1 & -345,000 \\ 1901 / 2 & -1,001,000 \\ 1902 / 3 & 464,000 \\ 1903 / 4 & 827,000 \\ 1904 / 5 & 315,000 \\ 1905 / 6 & 1,164,000 \\ 1906 / 7 & 1,585,000\end{array}$

The large losses experienced between 1900-1902 were due to expenditure incurred on outdated models and heavy depreciation of the stock of spare parts for these models, as well as losses on the hiring of commercial vehicles. Over the twelve-year period from 1896 to 1907 the company made profits of 3,547,000 francs of which 2,104,000 francs (59\%) were distributed as profits and 1,443,000 (41\%) put into reserves. From this it may be seen that from the very start Peugeot had a policy of re-investing a considerable part of its profits. So was Peugeot, at the turn of the twentieth century, a company that could be considered as a good lending opportunity for the bank. The analysts of the Crédit Lyonnais considered that the industrial and financial situation of the company was 'good and solid'. They then qualified this by noting 'Nevertheless because of the risks inherent in the automobile industry arising from the intense competition both from French and international companies, the company is not guaranteed to produce regular profits in the future' (CL, November 1908, p. 33). They were correct in this assessment because survival in the automobile industry at this time was difficult due to technological shocks ranging from changes in engine and chassis types to transformations in assembly line techniques.

The Peugeot family almost lost control of the company in the late 1920s due to financing problems. The Crédit Lyonnais blamed this policy on the arrival of three newcomers to the company between 1923-29 - Lucien Rosengart (1923-28) and Ricardo Gualino and Albert Oustric between 1928-30. Rosengart was first employed by the Peugeot family to assist in the financing of the company. His financing technique was to set up a separate company and to use it to borrow against the inventories held by Peugeot. He drew bills of exchange against these inventories and discounted them at the Banque de France, an activity that split the management of Peugeot during Rosengart's five year employment at Peugeot - see Loubet $(1999,179)$. He 
even briefly took over, as Managing Director from Robert Peugeot as a result of the latter's long illness. Rosengart, described as someone who 'passait pour avoir des idées originales en matière de construction automobile,' was criticized by the Crédit Lyonnais for changing the company's policy to one of expanding dividends at the expense of making sufficient provision for depreciation and increasing reserves. The analyst at the Crédit Lyonnais argued that rapid technological progress created the need for continuous re-tooling of factories suggesting that annual depreciations of 20 million francs should have been made rather than the 12 to 13 million francs as practiced between 1925-26 to 1928-29 at a time when dividend payments had been annually increased from 10 to 21 million francs. Rosengart was forced to resign in January 1929. Peugeot, in need of financial assistance, linked up with Gualino and Oustric. This was to be a very short arrangement for the bankruptcy of the latter's bank in 1930 led to considerable losses at Peugeot. The family took back control of the company appointing three out of the five board directors - Robert Peugeot, Jean-Pierre Peugeot and Jules Peugeot.

The brief association with financial controllers such as Rosengart and bankers such as Oustric, allied with the temporary move away from a policy of heavy reliance on selffinancing, created a near catastrophic result for the Peugeot family in the early 1930s. This experience appears to have hardened the family to returning to its tried and tested policy of investing through self-financing. Chadeau, describing how Peugeot emerged as the market leader between 1932-40 in France, focused on the self-financing strategy of the company:

...Peugeot's leadership decreed that each model launched had to be profitable in its own right, rather than as apart of a range. Whatever the rationale, the strategy made self-financing feasible and left family ownership intact. $(1993,195)$

Loubet observed that up to 1963 it is clear that Peugeot gave priority to reducing indebtedness or not taking on debt, quite the contrary to the approach of state owned companies, Simca and Renault (Loubet, 1995: 81). By the 1970s Peugeot was sufficiently large for it to acquire 90 per cent of Citroen's capital and then in 1977 it bought out Chrysler's European operations. Notwithstanding the acquisitions and mergers of Peugeot, and the use of dynamic outsiders such as Jacques Calvet and Jean-Pierre Folz as CEOs, the family's holding in Peugeot currently amounts to 27 per cent. Even more significantly the Peugeot family controls over $40 \%$ of the voting rights. The family's wealth was estimated at 2.67 billion euro in 2002 by Le Nouvel Economiste. 


\section{Conclusion}

This paper has attempted to show that historical phenomena have had a major impact in the determination of France's corporate ownership structure. Corporate finance is generated from three sources - banks, the capital market and self-financing. If we consider them as the three channels leading to corporate investment, then, history shows that two of these channels, the banks and the capital market, were subject to considerable upheaval rendering them inoperable as financing channels for a long period in France's corporate history. The major financial shocks arose as a result of the rise and collapse of John Law's Mississippi System and the hyper-inflationary experience generated by the assignats. These events traumatized the generation that experienced them. Furthermore, the strong oral tradition that emphasized the failures of Law and the assignats soured further generations towards financial innovation. Kindleberger (1989) emphasized the extent that these episodes traumatized the French:

There [France] the trauma of the Mississippi Bubble and the collapse of John Law's System slowed down the development of banking and the expansion of industry. Together with the collapse of the Directorate in the 1790s, it made the French neurotic, or even paranoid, about banking for years. (1989: 234)

The counterparts of this reaction against financial innovation was the continued recourse to notaires to fulfill a demi-banking role and the development of a strong specie holding mentality amongst the French. This in turn made it difficult for banks to develop fully even after the establishment of the big multi-branch banks, such as the Crédit Lyonnais and the Société Générale, in the 1860s. Faced with restricted access to the banks and capital markets, business entrepreneurs had to have recourse to a do it yourself approach, namely reliance on selffinancing as a method of growing their business. ${ }^{2}$ This restricted access, along with the banks'

\footnotetext{
${ }^{2}$ The question may well be posed that if the thesis of a weak banking and capital market structure is accepted what happened to the performance of the French economy. Initial economic research by scholars at the Research Center in Entrepreneurial History at Harvard, encapsulated in Landes (1969), suggested that the French economy had been backward relative to the British economy during the eighteenth and nineteenth centuries. Poor French entrepreneurship was put down as a causative factor to the inadequate performance. More recent quantitative research initiated by the Institut de Science Economique Appliquée, under the direction of Jean Marczewski, has challenged this retardationist approach and provided strong evidence that this was not the case - for a review of this literature see Cameron and Freedeman (1983). If this latter revionism is accepted then it may be argued that, because the French economy on average performed satisfactorily relative to its neighbours, the thesis that the banking and capital market structures were weak does not hold up. Two alternative interpretations may arise (1) the French economy would have produced even greater economic growth if it had been underpinned by a strong financial sector. There is a growing literature showing the way in which the financial sector has assisted total factor productivity - see, for example, Levine (1997) and Beck et al (2000). This literature would imply that if France had possessed a
} 
apparent willingness to invest outside France, may also have been responsible for having generated an anti-banking sentiment on the part of French entrepreneurs. This anti-banking sentiment was forcibly advanced by Louis Renault, the founder of Renault, when he stated:

Bankers are not philantrophists, they are money merchants and one should as often as possible not have any business with them. (Loubet, n.d.)

Self-financing in turn enabled these entrepreneurs and their descendants to retain sizeable shareholdings in the family controlled business. Hence, from an historical perspective, it is not surprising to see French families owning such a large proportion of French corporations. Examples of this reliance on self-financing drawn from the experiences of the Michelin, Bettencourt/Schueller, and Peugeot families have been shown above. Furthermore this style of ownership ties in with the French mentality that asset ownership is an inter-generational phenomenon. The objective of holding wealth is to pass on to the next generation of the family assets that, hopefully, have risen in value.

Though this does not square with the Berle and Means (1932) approach as to the way corporations should be owned and controlled it does not necessarily mean that the French owned corporations are less efficient than their American counterparts. Family control can enable companies to take long term investment decisions without all the emphasis of shorttermism that widely diffused stock market ownership may necessitate. While Landes (1949, 1969) was of the view that France was hobbled by family control of companies there is a strong counter argument to make that many of these family owned companies provided France with dynamic leadership promoting rather than retarding French economic activity.

This paper has emphasized the importance of history in the evolution of France's corporate ownership structure. There are of course other more recent elements that help explain the high degree of concentration of corporate ownership by families in France. The absence of funded pension schemes has led to a far lower profile by pension funds and assurance companies in the French stock market. In 1997 pension funds and assurance companies constituted 49\% of household savings in the United Kingdom and 30\% in the United States as against $18 \%$ in France. Recent industrial unrest in France has been exactly about this issue with trade unions arguing that it is the state that should provide long and generous pensions on a pay-as-you-go basis. The continuation of this approach to pensions implies, given the demographic structure,

more sophisticated financial sector between the eighteenth and twentieth centuries that it would have achieved an even higher rate of growth than that ascribed to it by economic historians; (2) the reliance on self-financing enabled entrepreneurs to make long-term investment decisions free from the constraints of a capital market emphasising short term results. 
that the percentage of GDP devoted to retirement payments will rise from 12 per cent at present to 16 per cent by 2040 . The consequences of this for taxation are probably unsustainable in the long run. If so, there will be increasing emphasis on funded pension schemes which will produce greater investment by pension funds and assurance companies in the French stock market.

Changes in governments in France produced waves of nationalizations between 1945 and 1982. More recently this process has been reversed. The privatizations of the Chirac government in the 1980s increased the number of French shareholders from 1.7 million in 1982 to 6.2 million in 1987 (Goldstein, 1996, 463).

The different corporate ownership structure in France, and, indeed, in many continental European countries, to that of the Anglo-American model raises the issue as to why there has not been a universalist convergence to the latter. Has it been due to the inadequate corporate governance in the civil versus the common law countries as La Porta et al. $(1998,2000)$ have stressed? This paper has tried to show that there have been strong historical factors at work that help explain France's current corporate ownership structure. One of these factors has been the way financial collapses, such as the Mississippi System, and the assignats have fashioned attitudes towards money, banks, credit and financial innovation - the major props of corporate finance. The Mississippi System - the biggest attempt at corporate re-structuring in the eighteenth century - and the assignats both aimed to remove the Midas fixation on gold in France and replace specie with banknotes and credit. Ironically, their respective failures actually reinforced the Midas fixation. The result of this was that financial innovation was frowned upon and the banking sector, from 1720 until the 1930s, was only allowed to grow within the constraints of a specie based monetary system. France's historical experience generated opposition to external finance that in turn led to internal finance and concentrated ownership. Another one of the historical factors highlighted in this paper is the different approach to inheritance. In France even if one wanted to disinherit the 'idiot heir' one could not do so. All one can do is to educate him/her. The French 'grandes écoles' have been intensively used by the large corporate owning families to ensure that their successors are capable to handling the 'patrimoine' in an appropriate manner. The continued participation of the Michelins and Peugeots in the management of the companies created by their ancestors in the nineteenth century shows the strength of the French family model.

Family control of companies is not necessarily the bad thing that some Anglo-American commentators make it out to be. Family ownership may prevent new blood coming into a 
company but sometimes the old blood is able to take a longer term perspective and to concentrate more resources on research and development than a young corporate raider whose leitmotif may be one of asset stripping at the expense of all that has been historically built up by a company. Evidence to support this view for France has recently emerged in Sraer and Thesmar's paper (2004). Furthermore for the U.S. Anderson and Reeb (2003) have shown that family owned owned companies in the S \& P 500 had a $6.65 \%$ better return on assets and that their assets and were valued $10 \%$ higher by the stock market in the U.S. Keeping it in the family may be good for not just the insiders but also outsider shareholders. 


\section{Bibliography}

Allouche, José and Bruno Amann (1995). 'Le retour triomphal du capitalisme familial' in De Jacques Coeur à Renault: Gestionnaires et Organisation (Presses de l'Université des Sciences Sociales de Toulouse)

Anderson, Malcolm (1965). 'The Myth of the Two Hundred Families'. Political Studies, June.

Anderson, Ronald and David Reeb (2003). 'Founding-Family Ownership and Firm Performance: Evidence from the S\&P 500'. Journal of Finance, vol. 58, no. 3.

Barca, Fabrizio and Marco Becht (2001). The Control of Corporate Europe (OUP, Oxford). Baskin, Jonathan and Paul Miranti (1997). A History of Corporate Finance (CUP, Cambridge) Beck, Thorsten, Ross Levine and Norman Loayza (2000). 'Finance and the Sources of Growth', Journal of Financial Economics, vol. 58.

Bellon, Bertrand (1980). Le Pouvoir financier et l'industrie en France (Seuil, Paris).

Berle, Adolf, and Gardiner Means (1932). The Modern Corporation and Private Property (MacMillan, New York).

Bloch, Laurence and Elizabeth Kremp (2001). 'Ownership and Voting Power in France' in Barca and Becht.

Blondel, Christine and Ludo Van der Heyden (1999). 'The Wendel Family: 'Affectio Societatis'. The Story of A French Industrial Dynasty (1704-1976)' (Working paper, INSEAD, Fontainebleau)

Blondel, Christine, N Rowell and Ludo Van der Heyden (2000). 'Prevalence of Patrimonial Firms on Paris Stock Exchange: Analysis of the top 250 Companies in 1993 and 1998' (Working Paper, INSEAD, Fontainebleau)

Bonin, Hubert (1988). Histoire économique de la France depuis 1880 (Masson, Paris).

Bonin, Hubert (1992). 'The Political Influence of Bankers and Financiers in France in the years, 1850-1960' in Cassis.

Cassis, Youssef (1992). Finance and Financiers in European History 1880-1960. (C.U.P., Cambridge).

Cameron, Rondo (1961, re-print 2000). France and the Economic Development of Europe 1800-1914 (Princeton University Press,1961; reprinted Routledge 2000).

Cameron, Rondo, Olga Crisp, Hugh T. Patrick and Richard Tilly (1967). Banking in the Early Stages of Industrialization (OUP, Oxford) 
Cameron, Rondo and Charles E. Freedeman (1983). 'French Economic Growth A Radical Revision' Social Science History, vol. 7 no. 1.

Chadeau, Emmanuel (1993). 'The Large Family Firm in Twentieth-Century France'. Business History, vol. 35 , no. 4, October.

Du Tot, [Nicolas] (1738). Réflexions politiques sur les finances et le commerce (Paul Harsin, ed. Paris, 1935).

Easterbrook, F.H. (1997). 'International Corporate Differences: Market or Law?' Journal of Applied Corporate Finance, vol. 9 no. 4.

Flandreau, Marc (2004). The Glitter of Gold. France, Bimetallism, and the Emergence of the International Gold Standard, 1848-73 (Oxford University Press)

Goldstein, Andrea (1996). 'Privatizations and Corporate Governance in France,' Banca Nazionale del Lavoro Quarterly Review, no. 199.

Gueslin, André (1992). 'Banks and State in France from the 1880s to the 1930s: the Impossible Advance of the Banks' in Cassis.

Harris, S.E. (193). The Assignats (Harvard University Press, Cambridge, Mass.)

Healy, Paul M. and G. Krishna Palepu (2003). 'The Fall of Enron' Journal of Economic Perspectives, vol. 17, no. 2.

Hoffman Philip T., Gilles Postel-Vinay and Jean-Laurent Rosenthal (2001). Des Marchés sans prix (EHESS, Paris).

Jammes, André (1998). Les Didot. Trois siècles de typographie et de bibliophilie 1698-1998 (Paris).

Kindleberger, Charles (1978; re-published 1898) Manias, Panics and Crashes (Macmillan, London)

Kindleberger, Charles (1984) A Financial History of Western Europe (Allen \& Unwin, London)

Landes, David S. (1949). 'French Entrepreneurship and Industrial Growth in the Nineteenth Century,' Journal of Economic History, vol. 9.

Landes, David S. (1969). The Unbound Prometheus (Cambridge University Press)

La Porta, Rafael, Florencio Lopez-De-Silanes and Andrei Shleifer (1998). 'Corporate Ownership Around the World', Journal of Finance, vol. L1V, no. 2, April.

La Porta, Rafael, Florencio Lopez-De-Silanes, Andrei Shleifer and Robert Vishny (2000). 'Investor Protection and Corporate Governance', Journal of Financial Economics, vol. 58. 
Lafaurie, Jean (1981) Les Assignats et les papiers-monnaies émis par l'état au XVIIIe siècle (Le Léopard d'Or, Paris)

Law, John (1934). Oeuvres Complètes ed. Paul Harsin, (Paris)

Levine, Ross (1997). 'Financial Development and Economic Growth: Views and Agenda' Journal of Economic Literature, vol. 35.

Lévy-Leboyer, Maurice (1964). Les Banques européennes et l'industrialisation internationale dans la première moitié du XIXe siècle (P.U.F., Paris)

Lévy-Leboyer, Maurice (1980). 'The Large Corporation in Modern France' in Chandler, A. and Daems H. (eds.). Managerial Hierarchies: Comparative Perspectives on the Rise of the Modern Industrial Enterprise (Harvard University Press)

Lottman, Herbert (1998). Michelin 100 ans d'aventures (Flammarion, Paris)

Loubet, Jean-Louis (ed.). Citroen, Peugeot, Renault. Histoire de stratégies d'enterprises

Loubet, Jean-Louis (ed.) (1999). L’Industrie automobile 1905-1971 (Droz, Geneva).

Luthy, Herbert (1959). La Banque protestante en France (S.E.V.P.E.N., Paris).

Murphy, Antoin E. (1986). Richard Cantillon: Entrepreneur and Economist (OUP, Oxford).

Murphy, Antoin E. (1997). John Law: Economic Theorist and Policy-Maker (OUP, Oxford).

Plessis, Alain (1992). 'Bankers in French Society 1860s-1960s' in Cassis.

Pollard, Sidney (1985). 'Capital Exports, 1870-1914'. Economic History Review, $2^{\text {nd }}$ ser. 38, November.

Rajan, Raghuram G. and Luigi Zingales (2001) 'The Great Reversals: The Politics of Financial Development in the $20^{\text {th }}$ Century' NBER Working Paper 8178 (Cambridge, Mass.)

Teneul, G.F. (1961). Le financement des enterprises en France depuis la fin du XIXe siècle à

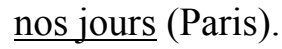

Turgot, Anne Robert Jacques (1769/70). 'Réflexions sur la formation et la distribution de la richesse' in Éphémérides du citoyen, vols. 11-12 (1769) and vol. 1 (1770).

Turgot, Anne Robert Jacques (1749, [1913]). Oeuvres de Turgot ed. Gustav Schelle (Alcan, Paris)

Say, Léon and Joseph Chailley (1891). Nouveau dictionnaire d'économie politique (Paris).

Sraer, David and David Thesmar (2004) 'Performance and Behavior of Family Firms: Evidence from the French Stock Market'. Unpublished paper, CREST-INSEE, Malakoff, France.

White, Eugene (1989). 'Was there a Solution to the Ancien Régime's Financial Dilemma' Journal of Economic History, Vol. 49. 


\section{Chart 1}

Factors Influencing France's Corporate Ownership Structure

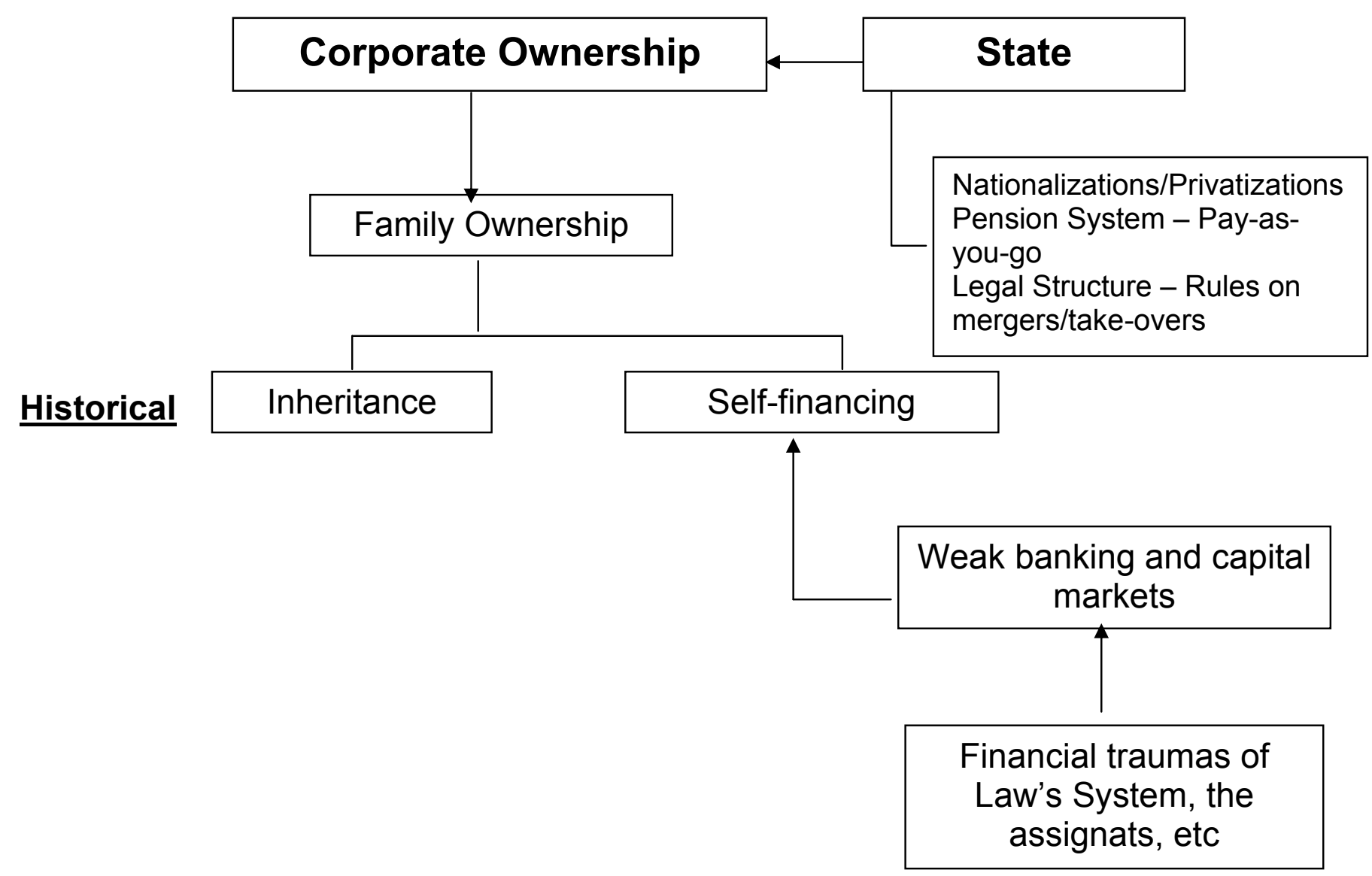

